\title{
Atlantis
}

Critical Studies in Gender, Culture \& Social Justice

Études critiques sur le genre, la culture, et la justice

\section{Regendering the Canadian Armed Forces}

\section{Victoria Tait}

Volume 41, Number 2, 2020

Gender and the Canadian Armed Forces

URI: https://id.erudit.org/iderudit/1076197ar

DOI: https://doi.org/10.7202/1076197ar

See table of contents

Publisher(s)

Mount Saint Vincent University

ISSN

1715-0698 (digital)

Explore this journal

Cite this article

Tait, V. (2020). Regendering the Canadian Armed Forces. Atlantis, 41(2), 9-25. https://doi.org/10.7202/1076197ar

\section{Article abstract}

Although feminist scholars agree that there exists a systemic relationship between masculinity and militarism, the exact contours of that relationship are debatable. Most feminists argue that as a primary goal, the women's movement ought to seek approaches for the abolition of militarism, rather than using women's participation in the military as a means of enhancing gender equality. Despite admonitions about the dangers of pursuing gender equality through military service, feminists must also weigh these concerns against women's advances within the military and the use of the military in peacekeeping and humanitarian operations, both of which are essential to the Women, Peace and Security agenda. This article therefore turns a critical feminist lens on theories of military re-gendering. I explore whether military organizations that have traditionally valorized militarized masculinity can be transformed-both at an individual and systemic level-to embrace an egalitarian iteration of masculinity and contribute to a more peaceable international system. To examine the possibility of regendering in the Canadian Armed Forces (CAF), I review 17 interviews that I conducted with members of the CAF from 2017-2018 using theories of military regendering. My analysis indicates that servicemembers are engaging in critical examination of the military's gender culture, and their position within that culture. By critically engaging with questions about the relationship between gender and militarism, military personnel may be participating in the incremental—and fragile-process of improving the gender culture of the CAF.
All Rights Reserved @ Victoria Tait, 2020

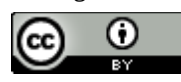

This document is protected by copyright law. Use of the services of Érudit (including reproduction) is subject to its terms and conditions, which can be viewed online.

https://apropos.erudit.org/en/users/policy-on-use/ 


\section{Regendering the Canadian Armed Forces}

Victoria Tait is a PhD candidate in the Political Science Department at Carleton University (Ottawa). Her research focuses on feminist security studies, and her dissertation examines how Women, Peace and Security policy has been framed and implemented within the Canadian Armed Forces. She works directly with Canadian soldiers to identify challenges in the military's gender culture(s) while creating space for female-identifying soldiers to shape the academic and political narrative of their experience. Victoria's work has appeared in the Canadian Defence Academy Press, Springer Publishing, Sage Research Methods Cases, and SITREP: The Journal of the Royal Canadian Military Institute. She has held doctoral grants from the Social Sciences and Humanities Research Council of Canada, Ontario Graduate Scholarship Program, and has been awarded the Women in International Defence Memorial Scholarship (2016) and the Franklin Pinch Award for Best Graduate Student Paper at the Inter-University Seminar on Armed Forces and Society Canada (2018).

Abstract: Although feminist scholars agree that there exists a systemic relationship between masculinity and militarism, the exact contours of that relationship are debatable. Most feminists argue that as a primary goal, the women's movement ought to seek approaches for the abolition of militarism, rather than using women's participation in the military as a means of enhancing gender equality. Despite admonitions about the dangers of pursuing gender equality through military service, feminists must also weigh these concerns against women's advances within the military and the use of the military in peacekeeping and humanitarian operations, both of which are essential to the Women, Peace and Security agenda. This article therefore turns a critical feminist lens on theories of military regendering. I explore whether military organizations that have traditionally valorized militarized masculinity can be transformed-both at an individual and systemic level - to embrace an egalitarian iteration of masculinity and contribute to a more peaceable international system. To examine the possibility of re-gendering in the Canadian Armed Forces (CAF), I review 17 interviews that I conducted with members of the CAF from 2017-2018 using theories of military regendering. My analysis indicates that servicemembers are engaging in critical examination of the military's gender culture, and their position within that culture. By critically engaging with questions about the relationship between gender and militarism, military personnel may be participating in the incremental — and fragile-process of improving the gender culture of the CAF.

Keywords: Canadian Armed Forces, feminist, gender, military

The views expressed here are solely those of the author, and they do not reflect the views and values of the Department of National Defence or the Canadian Armed Forces. This research project has been approved by the DGMPRA Social Science Research Review Board, in accordance with DAOD 5062-0 and 5062-1. The SSRRB approval \# is $1638 / 17 F$. 
U nited Nations (UN) Security Council resolution 1325 (2000), which initiated the global Women, Peace and Security (WPS) agenda, has been adopted into National Action Plans in 86 UN member states (Peacewomen.org 2020) as well as in international organizations like the UN and NATO (Davies and True 2018). The WPS agenda can be distilled into two key areas of focus: the importance and enhancement of women's participation in international processes of peace and security, with a particular emphasis on women's roles in the prevention and cessation of violent conflict, and the recognition and remediation of the inordinate impact of conflict on women and children (United States Institute of Peace 2020). Although it would be incorrect to essentialize all women as inherent peacemakers, a flaw that several prominent scholars argue is embedded in discussions on the WPS agenda (El-Bushra 2007; Shepherd 2011), women's antiwar movements have provided a vital source of labour, organization, and thought toward the advancement of a more peaceable international order (Etchart 2015). The WPS agenda is rooted in decades of women's peace activism; from the founding of the International Council of Women in 1888 to the work of the United Nations Working Group on Women, Peace and Security today, women's antiwar activism has served as an organizational backbone for the peace movement (Ibid.). This activism is undergirded by a vast body of academic research, which has demonstrated that women and children suffer the deleterious effects of conflict in ways that differ from the experiences of men (see Davies and True 2018; Lorentzen and Turpin 1998). Although feminist security scholars agree that there exists a systemic relationship between masculinity and militarism, the exact contours of that relationship — and possibilities for change - are debatable (Duncanson 2009; Duncanson and Woodward 2016; Higate 2007; Sjoberg and Via 2010). Most feminists argue that as a primary goal, the women's movement ought to seek approaches for the eradication of militarism, rather than using women's military participation as a channel for enhancing gender equality (see Cockburn 2010; Frazer and Hutchings 2014; Peach 1997).

Despite admonitions about the dangers of pursuing gender equality through militarist channels, there is a growing awareness that feminists must take seriously the changes to the international security environment following the end of the Cold War (Duncanson 2009; Duncanson and Woodward 2016). After the collapse of the Soviet Union (1991), instances of interstate warfare declined, while nation-building processes amongst former Soviet satellite states prompted an upsurge in violent civil wars, many of which ended in brutal genocides (Mann 2018). The increase in civil war has been met with widespread agreement amongst UN member states that if a state cannot protect its people from genocide, the international community has a responsibility to protect the people of the affected state, through military intervention if necessary (United Nations 2005). Modern humanitarian interventions and peacekeeping operations are therefore reliant on national armed forces to provide security, enforce peace mandates, and distribute goods and resources. These requirements, alongside an increase in servicewomen in the member states of NATO forces, have prompted several scholars to re-engage with the military to discern if national and coalition forces can be relied upon as credible sources of security and, ultimately, peace (Bastick and Duncanson 2018; Duncanson 2015).

The question of whether militaries are capable of advancing peace is indeed difficult and multifaceted. Many militaries entrusted with peacekeeping duties are themselves guilty of employing troops that have committed human rights abuses; though disagreement remains about the degree to which the guilt for these abuses lay in the military in a systemic sense, or with the soldier(s) involved. Feminist security scholars see the issue of human rights abuses during warfare-and warfare itself - as systemic issues; these abuses are imbricated in the militarized international system itself (Cockburn 2011; Eichler 2014; Enloe 2014, 2014; Sjoberg 2013; Sjoberg and Via 2010; Whitworth 2004). From this perspective, war crimes are rooted in the larger historical trajectory of patriarchy; an inegalitarian gender order that ensures the dominance of men and the subservience of women through sociohistorically contextual gender norms. Within this system, gender norms surrounding masculinity have been reinforced by the practices and discourse of militarism. 
Maya Eichler (2014) further defines the process of militarizing masculinity as one in which, "what it means to be a man in a particular time and place becomes closely tied to the military-militarism and masculinity reinforce each other," and together, subordinate women and femininity in domestic and global systems of power (Eichler 2014, 83). For example, within North American society during WWII, military service was seen as a source of authentication of men's strength, bravery, and patriotism while men who did not enlist were chastised through jeers designed to emphasize their fragility and passivity; qualities only deemed acceptable in women (Canaday 2003; see also Bulmer and Eichler 2017; Eichler 2014; Nagel 1998). Historical processes like these are believed to have created and sustained "the gendered dichotomies that are instrumental in the persistence of violence, such as the association of combat with masculinity and peace with femininity" (Duncanson and Woodward 2016, 7). Within this view of the military, relying on the armed forces to assist in the pursuit of a more egalitarian, peaceable international order may seem an unlikely approach.

As unlikely a vehicle as the military is for advancing peace, Canadian feminist scholars would be remiss not to explore possibilities for change in the Canadian Armed Forces (CAF), particularly as women continue to be targeted in modern recruitment efforts by the organization (Berthiaume 2020). This article therefore turns a critical feminist lens on theories of military regendering; I explore whether military organizations that have traditionally valorized militarized masculinity, like the CAF, can be transformed-both at an individual and systemic level-to embrace an egalitarian iteration of masculinity and the creation of a more peaceable international system (Bastick and Duncanson 2018; Duncanson 2009, 2015). This is a particularly salient debate in the Canadian context, as the CAF has been repeatedly exposed by news media and reprimanded by civilian politicians and the Canadian public for the persistence of sexual misconduct within its ranks; it is now re-evaluating its culture in an effort to eliminate sexual misconduct (Connolly 2020; Deschamps 2015; O'Hara 1998; Statistics Canada 2018). Therefore, the culture of the CAF, and its gender culture in particular, are of key interest to Canadian policy makers. My contribution to this special issue ends on a hopeful note. My research demonstrates that the CAF is at a critical juncture in the process of identifying and dismantling the hegemony of masculinity premised on violence and domination. This stage is what Claire Duncanson (2015), drawing on R.W. Connell's works (1995, 2002a, 2002b, 2005; Connell and Messerschmidt 2005) refers to as a "transitional" stage in the "re-gendering" of hegemonic masculinity, a stage where "hegemonic masculinity shifts to adopt traits, practices, and values that are conventionally associated with femininity" (Duncanson 2015, 241). It is through this "softening" of hegemonic masculinity that more egalitarian iterations of what it means to be a servicemember can begin to take hold.

To examine the possibility of regendering in the CAF, I critically examine 17 interviews that I conducted with members of the CAF in late 2017 through 2018 using theories of military regendering introduced by Claire Duncanson, Rachel Woodward, and Megan Bastick (see Bastick and Duncanson 2018; Duncanson 2009; Duncanson 2015; Duncanson and Woodward 2016). In doing so, I am responding to Duncanson and Woodward's (2016) call for increased research on "military personnel's self-understandings in terms of both their gendered subjectivities and their position within gendered organizations" (14). My analysis indicates that servicemembers are engaging in critical examination of the military's gender culture, and their position within that culture. ${ }^{1}$ More broadly, servicemembers recognize that diverse gender experiences are valuable within the CAF, and that hypermasculine performances of masculinity can be detrimental to the goals of the organization. By critically engaging with questions about the relationship between gender and militarism, military personnel may be participating in the incremental-and fragile-process of transforming the gender culture of the military (Duncanson and Woodward 2016, 12). The question remains however: will this transitional period lead to the erosion of violent masculinity within the gender culture of the CAF? Or will it simply shift to a more insidious variant, better adapted to achieving militaristic goals by using the language of modern liberal democracy? While it is too 
early to assess the end results of this process, I argue that feminists' sustained engagement with the CAF has produced positive change within the culture of the military, and that continued engagement will remain essential to secure progress. I place the discussion of regendering the CAF in conversation with feminist and post-colonial critiques, as discussed in the following section. I close with some suggestions on how we might anticipate the outcome of this shift.

\section{Masculinities and the Combat Masculine Warrior Paradigm: A Canadian Perspective}

Theories of military regendering have emerged in the context of changes in the operational scope of NATO missions and the composition of NATO forces, including the CAF. The priorities and composition of NATO forces have changed considerably since the end of the Cold War; as of 2018, women represented $25 \%$ of NATO's senior management (NATO 2018). Though deterrence remains a key concern, a new emphasis has been placed on counterinsurgency and stabilization operations, and therefore closer collaboration with local people in the nations where NATO and UN troops are stationed. Duncanson (2015) argues that we can begin to see how changing military demographics in combination with a shifting security paradigm are disrupting masculinist norms. This shift has driven an increased emphasis on the importance of consensus, peacebuilding, and cooperation, which requires that soldiers exercise traits and capabilities that have been traditionally regarded as feminine (Ibid., 235, 241; see also Duncanson 2009). Furthermore, these changes are complemented by the diversifying composition of many NATO forces; all treaty members have now opened combat positions to female personnel (Duncanson 2015, 238). Amidst these changes, Duncanson highlights new socio-historical conditions that could undermine the hegemonic masculinities within the military that are premised on violence and domination. Building on Connell's collected works, Duncanson suggests that the two-stage process through which we can begin to see this transformation in military gender culture is: (a) the transitory stage where "the hegemonic masculinity shifts to adopt traits, practices and values which are conventionally associated with femininity" and (b) a "disposition towards equality and democracy" emerges among genders. Thus, change must be measured not just in change towards the practices associated with masculinity, but in the relational interactions between genders and within gender groupings (241). Similarly, Georgina Waylen and Louise Chappell (2013) refer to these transitional periods as crisis tendencies within masculinized institutions, wherein the "inherent instability and internal contradictions" of masculinity render the institution vulnerable to feminist pressures to transform its gendered nature (603).

In "Hegemonic Masculinity and the Possibility of Change" Duncanson (2015) conducts a comprehensive review of existing literature on militarized masculinities, with a particular focus on Connell's seminal work on hegemonic masculinity. Duncanson's literature review emphasises the hegemony of a "combat-oriented masculinity" within North American and European militaries, characterized by violence, domination, and "heterosexual prowess"; she suggests that this iteration of masculinity has been "linked to violence against women by soldiers, including the use of rape as a weapon of war, domestic violence, and sexual exploitation of women on peacekeeping operations" (Ibid., 235). Hegemonic masculinity in this instance works to transcend the ethnic and class-based divisions that permeate the culture of military personnel in order to coalesce around a shared ideal warrior type, ultimately fusing the social construction of masculinity with bellicosity and femininity with "weakness and passivity" (Ibid.). This creates an environment wherein team cohesion is premised on adherence to aggressive and violent iterations of masculine identity. This is not to suggest that masculinity is somehow inherently bad, rather that in order to achieve hegemony over other expressions of gender, hegemonic masculinity has adopted traits we might consider toxic, such as belligerence and hostility (Cockburn 2011; Eichler 2014; Hinojosa 2010; Sjoberg 2009; Whitworth 2004). Sandra Whitworth (2005) argues that these qualities can become wedded to masculinity through processes of military indoctrination; "qualities demanded by militaries, such as the requisite lust for violence when needed and a corresponding willingness to subordinate oneself to 
hierarchy...must be self-consciously cultivated...[as] few new male recruits arrive as ready-made soldiers" (99). Accordingly, new recruits must become assimilated into a socio-historically specific iteration of masculine culture that reshapes civilian inclinations and teaches military personnel to serve (and kill) at the behest of the state. Traditionally, these conditions promote bellicose iterations of masculinity while femininities and subordinate masculinities are de-valorized (Peterson 2007, 10).

Theories of hegemonic masculinity emphasize that although gender norms are socially constructed, gender performances will be judged against a standard or ideal of masculinity that has become hegemonic within a given socio-historical moment. Accordingly, someone in a body coded as male may not meet masculine ideals; they may fail to meet these socially constructed standards, or they may disregard them of their own volition. Likewise, someone in a body coded as female may not perform in ways that are considered feminine, or they may fail in their attempt to live up to the standards of idealized masculinity in the case of military service. For example, a 2003 study on female leadership in the CAF combat arms found that four of the eight female leaders interviewed warned against adopting traditionally feminine roles and attributes, arguing "you do have to have a certain degree of, kind of non-sexuality about you....as a leader in the combat arms, you don't want men to think a certain way, you cannot dress like that when you go to a military social function" (Febbraro 2007, 111). These gender performances are seen not simply as subordinate to masculinity but are capable of "contaminating" it as in the case of "pariah femininities" (Schippers 2007, 95). Pariah femininities, like that of the "lesbian" or "slut" for example, are seen to distort the idealized relationship between aggressive men and passive women and are subject to particularly stringent stigmatization and punishment (Ibid.). Mimi Schippers' work emphasizes that although many gender identities exist across the gender spectrum, only certain gender performances will be rewarded, while others receive punishment from the dominant gender culture.
As feminist security scholars now realize, women's security and labour are both profoundly degraded in humanitarian crises and during periods of conflict (see Report of the Secretary General on Women, Peace and Security 2019). As a result, practices of militarized masculinity perpetuate a violent, inegalitarian gender order through systems of state-sanctioned belligerence, while feminized persons and institutions are marginalized. I argue that these gender norms are not inexorable, and that hegemonic masculinity can be weakened, though the process is difficult to initiate and it is certainly not immune to regression. Similarly, Duncanson and Woodward (2016) reject deterministic arguments that militaries must necessarily remain bastions of militarized masculinity, and instead suggest that seemingly small changes in military culture (for example in personnel, or in operational approaches) can, over time, produce radical transformations in gender culture. As they explain:

A re-gendered soldier assumes a peacebuilder identity that is equally open to women and men, that equally values "masculine" and "feminine" traits, so much that they cease to become masculine and feminine.... In such a military, soldiering is not a masculine identity, but becomes much more fluid, and is constructed through relations of equality, empathy, care, respect and recognition of similarities and shared experiences. (Ibid., 12)

The authors recognize the value of hegemonic masculinity theory but reject the pessimistic determinism inherent in how Connell's work has been interpreted; as feminists we must continue to explore-through theory and empirical research-how violent iterations of hegemonic masculinity "may fail" (Duncanson 2015, 232). Importantly, Duncanson's approach allows for a theorization around the dominance of masculinity in the ritual, history, and practice of the CAF without rendering invisible servicewomen's work to transform the institution (see also Davis 2007, viixiv).

Although I argue below that the CAF has entered a transitional period in the erosion of masculinity wherein the viewpoints of servicemembers have be- 
come more open to gender performances traditionally considered feminine, it is important to take stock of the challenge that lies ahead for the organization. As Matthew Hurley (2018) notes in an analogous study with two NATO military men, gender norms are being renegotiated "through mutual respect, empathy and interdependence," but at this stage they are "embryonic, not hegemonic" (87). Therefore, the changes to the CAF's gender culture detailed in this article are promising but are by no means immune to relapse into the kinds of militarized masculinity that Whitworth (2004) and others have highlighted. To begin, there is evidence that militarized masculinity remains a problem within the CAF, and that this form of militarized masculinity remains violent and exclusionary (Mercier and Castonguay 2014; Deschamps 2015). This problematic form of masculinity is encapsulated in Karen Dunivin's (1994) "combat masculine warrior paradigm" (533). In her examination of the American military cultural paradigm, Dunivin emphasizes that the military exists to enable and prepare for "the conduct of war" while the institution itself is "comprised primarily of men, its culture is shaped by men.... Thus a deeply entrenched cult of masculinity (with accompanying masculine norms, values and lifestyles) pervades military culture" (Ibid.). In a military culture where this iteration of masculinity is hegemonic, women "may not be regarded as real soldiers until they are able to do what 'real' soldiers do which is to kill and die in combat" (Ibid., 534). Within a combat masculine warrior paradigm, the "soldier's world is characterized by a stereotypical masculinity. His language is profane; his professed sexuality rude and direct; his maleness is his armor, the measure of his competence, capability and confidence in himself” (Marlowe 1983, 192 cited in Carreiras 2006, 42). Even if the reader accepts that segments of the CAF are transitioning to egalitarian gender relations, the ubiquity and historical endurance of the combat masculine warrior paradigm is likely to present an obstinate challenge to a reformed military gender culture.

Canadian studies on masculine norms in the military (Davis 2007; Lane 2017; Taber 2017, 2018; Tait 2015; Winslow and Dunn 2002) have revealed the continued prevalence of the combat masculine warrior paradigm within the Canadian military following the removal of combat barriers to women in 1989. Early studies demonstrated that this challenge was particularly pronounced within the "combat arms" of the CAF (Canada 1998). The "combat arms" refers to trades that are responsible for direct engagement: infantry, armoured, artillery, and combat engineers. Today these trades still contain very few servicewomen; just $2.9 \%$ in the Regular Forces and 6.7\% in the Primary Reserves (Canada 2019, 9). Although militarized masculinity will vary by time and place, and the definitions used here are indicative of the context within which they are embedded, these militarized masculinities tend to share a predisposition towards valorizing the effective performance of violence and dominance through physical strength. The consequences of indoctrinating Canadian servicemembers to value and perform violent masculinity are significant. As feminist scholars have demonstrated, militarized masculinity in training practices and rituals may have helped incite the 1993 Somalia Affair, which involved horrific human rights abuses culminating in the beating, torture, and murder of Somali teenager Shidane Arone by the Canadian Airborne Regiment (Whitworth 2004; Razack 2000). The Canadian Airborne Regiment was disbanded after the incident, but not before the Somalia Inquiry revealed its racist, alcohol-laden hazing rituals, which many argue aided in cultivating the violent behaviour witnessed in Somalia (Whitworth 2004; see also Razack 2000; Winslow 1999, 2000). These rituals inculcated a brutal iteration of militarized masculinity in their participants; masculinity within these training rituals was premised on domination, scoffing at gender and racial equality, and violent heterosexual performances (Razack 2000; Whitworth 2004). Five years after the Somalia Affair was made public, a series of articles in Maclean's (O'Hara 1998) detailed the horrendous sexual abuse that servicewomen had been forced to endure during their training and deployment with male CAF members. Women in the Maclean's interviews recall that trainees were told to "hate women and officers" and that this behaviour was "copied by other male recruits" (Ibid., 3). Recent studies, like the 2015 External Review into Sexual Misconduct and Sexual 
Harassment in the Canadian Armed Forces (also known as the Deschamps report, after former Supreme Court Justice Marie Deschamps who headed the review) and Statistics Canada reporting (2018) have illustrated that both gender-based discrimination and sexual misconduct remain a challenge in the CAF to this day (Deschamps 2015; Statistics Canada 2016, 2018).

\section{Methods}

In this paper I analyze 17 semi-structured interviews I conducted with Regular and Reserve CAF personnel in late 2017, through 2018. These semi-structured interviews lasted approximately one hour and focused on understanding how UNSCR 1325 on Women, Peace and Security has been framed and communicated to CAF personnel as part of my larger, related project on norm translation in the CAF and the Canadian WPS agenda. The interviews also provided an opportunity to discuss the suite of CAF initiatives aimed at integrating gender and changing military culture, including Operation HONOUR and Gender-based Analysis Plus (GBA+). Operation HONOUR, initiated in 2015 by Chief of Defence Staff Jonathan Vance refers to a CAF-wide initiative to eliminate sexual misconduct amongst troops, sailors, and aviators. GBA+ refers to Gender-Based Analysis Plus, a Canadian governmental initiative administered by Women and Gender Equality Canada that seeks to utilize an intersectional gendered lens to assess the impact of Canadian governmental policies and programs on diverse groups of Canadians. I coded responses to the interview questions as "positive" or "negative" or in some cases "not applicable" where the participant felt they could not comment given their experience. Several of the interview questions focused exclusively on gender as a concept and the importance of gender in military operations and are therefore well-suited to tackle the inquiry pursued in this article. The interviewees were recruited using a snowball methodology, focusing on participants with 5+ years of service (YOS), and preferably at least one deployment (international or domestic). The interview population breakdown is shown in Table 1 .

This modest sample is not designed to be representat-
Table 1. Interview Participant Population. $\mathrm{n}=17$

\begin{tabular}{|l|l|l|}
\hline \multirow{3}{*}{ Gender Identity } & Men & 7 \\
\cline { 2 - 3 } & Women & 10 \\
\cline { 2 - 3 } Component & Gender non-conforming & 0 \\
\hline \multirow{2}{*}{ Rank } & Regular Forces & 7 \\
\cline { 2 - 3 } & Reserve Forces & 10 \\
\hline \multirow{3}{*}{ Deployment History } & Non-Commissioned Members & 6 \\
\cline { 2 - 3 } & Officers & 11 \\
\hline \multirow{2}{*}{ Occupation } & $\begin{array}{l}\text { 1+ Deployment on Expeditionary } \\
\text { Mission }\end{array}$ & 13 \\
\cline { 2 - 3 } & 0 Deployment on Exp. Mission & 4 \\
\hline \multirow{2}{*}{ Years of CAF Service } & Operators & 9 \\
\cline { 2 - 3 } & Support & 8 \\
\hline \multirow{5}{*}{ Element } & Average & 19 Years \\
\cline { 2 - 3 } & Median & 17 Years \\
\hline & $\begin{array}{l}\text { Air } \\
\text { (Royal Canadian Airforce - Aviators) }\end{array}$ & 3 \\
\cline { 2 - 3 } & $\begin{array}{l}\text { Sea } \\
\text { (Royal Canadian Navy-Sailor) }\end{array}$ & 1 \\
\cline { 2 - 3 } & $\begin{array}{l}\text { Land } \\
\text { (Canadian Army - Soldier) }\end{array}$ & 13 \\
\hline
\end{tabular}

ive of the CAF population. Rather the goal is to provide a snapshot of perspectives and attitudes amongst servicemembers in the CAF. The responses have been used to determine if processes of regendering, as described by Duncanson, Woodward, and Bastick, are evident in the Canadian military. This sample constitutes experienced servicemembers (both in years of service and in deployment history) and tends to favour officers and Army personnel, while over-representing personnel that identify as women. Soldiers were not asked their sex or gender in this study, but rather if they identify with a "masculine or feminine gender, either, both, or neither?" In this regard, I aim to understand how my participants negotiate their subjective gendered experience through an approach informed largely by post-structural feminism (Butler 2011; Connell 1995); this allows participants to consider their understandings of war and conflict, their relationships with colleagues, their bodily performances of gender, and those of their peers.

\section{Results}

To establish a standard amongst participants, I quantitatively analyzed responses to four of the interview questions, starting with participants' attitudes towards women in combat. All 17 participants responded in ways that I coded as positive when asked, "Generally speaking, what do you think about women serving in the combat arms?" We can therefore discern that, in 
the most basic sense, the participants have no opposition to women in combat roles and in the CAF more generally. The second question asked, "When Canada sends troops on a United Nations mission, should one or more of the authorized positions be reserved for Gender Advisors (GENADS) — and do you think they should be women, men, or either?" GENADS are Canadian military personnel trained to advise commanding officers, peers, and subordinates on gender-based issues in operations, training, and personnel policies within the CAF. In response to this prompt, two participants rejected the notion of deploying GENADS on UN missions, and the remaining 15 responded that GENADS should be deployed and that the work could be completed by any gender. Third, after discussing Canada's implementation of UN Security Council resolution 1325 on Women, Peace and Security and related CAF gender integration initiatives, I asked participants if their "experience in the military suggests that there is a need for this kind of guidance? Why or why not?" 12 participants responded that their experience suggests a need for this guidance, two suggested that there was no need, and three responses were registered "N/A." Finally, when asked if they "believed that gender-sensitive rules and regulations ${ }^{2}$ allow you to better complete your job as a soldier [or sailor/aviator], why or why not?" 11 participants answered affirmatively, one did not believe that current rules and regulations were useful, and five servicemembers did not believe that they could answer given that they had not had, in their opinion, an opportunity to apply these principles. The majority of participants therefore had positive attitudes towards servicewomen, improving gender awareness in the CAF, and expanding gender perspectives in operations.

Although many of my participants espoused positive views towards servicewomen (in combat and in general), existing research calls for caution in interpreting the results of my study too optimistically as my participant group contained a disproportionate number of officers and women in comparison to the CAF's general population. Officers have generally received more education than non-commissioned members (NCMs) through civilian and military programming and hold leadership positions within the CAF (Gill and Febbraro $2013,280)$. It is therefore possible that my participants hold more positive views towards women and the integration of gender-based analysis in the CAF than the broader CAF membership. However, my participants demonstrate that attitudes towards marginalized communities in the CAF are shifting - even within those areas of the military that we might expect members would hold fewer progressive views than their peers. Recall that women were excluded from combat service in Canada until 1989, and combat trades still contain a very low percentage of servicewomen (Canada 2019). An infantry officer with $10+$ YOS discussed how he has pursued more considerate interactions with his peers in the CAF by highlighting that he had long since eliminated misogynistic and homophobic language from his vocabulary. He recounted that the Deschamps report had been a turning point for him; even if "everything everyone says about it - that is bad-is true, let's just realize that even if there's a tiny bit of truth to this report, all we have to do is to stop saying [derogatory homophobic and misogynistic terms]." He went on to say that he was not interested in being part of the army that is depicted in the Deschamps report. This quote shows not only that masculinities traditionally considered subordinate (in this interview context, gay men) are accepted within his community, but that in his view, homophobia and misogyny are in direct contradiction of his values. Another infantry officer with $30+$ YOS argued that "[in] planning and analysis...I find when there's too much testosterone in the room, we tend to overlook certain key factors that need to be considered...." He went on to state that he is unsatisfied with the current slate of gender training available to him in the CAF because, "it's not robust enough." Similarly, a non-commissioned officer from the armoured trade with 20+ YOS explained that he was interested in gender perspectives

from the point of view that you want to be a better facilitator, a better leader...you need to accept that this is here to stay and it's not an old boys' network approach anymore. In order to be a decent human being you've got to do that sort of stuff.... There's a lot more in the world than middle aged white dudes, and you have to think about that and it's not just gender, its ethnic- 
ity.... It's different ways that people perceive what you're doing.... and how you carry out your role and your job.

This soldier's emphasis on the importance of diversity to soldiering was echoed by a non-commissioned member within the armoured trade who argued that "Having our different genders is what makes us unique as Canadian soldiers and since we have such a small force, we need to have all the diversity we can in our forces, because we're a thinking army. It's not just 'here's a rifle, shoot,' right?" This connection was reiterated by an infantry officer with $15+$ YOS who stated that one of the female platoon commanders he was deployed with was

much better than the rest of us to be brutally honest, at building relationships with our senior NCOs, and... anytime she was making a decision, they were fully involved in that decision making process and it came more naturally... the decisions were being made as a group, and so you already had buy-in from your subordinates.

Although this constitutes only a small selection of the discussions I shared with male-identifying combat arms soldiers, it suggests that within these communities, the valorization of exclusionary masculinity is weakening. Progressive attitudes regarding gender have emerged amidst growing experience working with servicewomen, and these attitudes may help to erode the traditional combat masculine warrior paradigm.

My interviews also show that there is a parallel trend of embracing traditionally feminized attributes in operations. This coincides with entering the transitional phase in the erosion of hegemonic masculinity and a move to democratic gender relations (Duncanson 2015). In particular, servicemembers in my interviews were keen to emphasize the value of feminized attributes on deployment, such as the importance of compassion and sensitivity when dealing with trauma survivors, and used gendered perspectives to achieve humanitarian goals. A senior NCM with $20+$ YOS discussed that during her deployment, she found her gender identity essential as it allowed her "access to people that I wouldn't have had access to if I had been a male...I was able to meet with the families of mullahs and gain their trust in a different way that my male counterparts would never have been able to engage in." Examples of women using their gender identity to more effectively "infiltrate" host communities are frequently articulated in NATO manuals on gender integration; they do not in-and-of themselves represent a transformative viewpoint on gender. However, my interviewee went on to argue for the importance of gender-based perspectives stating that, "the majority of refugees are women and children and if you're dealing with a delicate population then you need to be aware of the traumas that they've suffered at the hands of their aggressors and how that's going to affect how they receive the military." This observation suggests that this soldier has not simply used her gender identity to better influence or manipulate civilian populations, but that she recognizes the importance of gender-based analysis to ensuring more thoughtful care of vulnerable peoples, an effort that is entirely in line with peaceable feminist priorities.

Similarly, a combat arms officer emphasized that she reached out to the NATO GENAD during her deployment to see how she could best assist her in bringing gender aware perspectives to the mission. When the GENAD responded that she should be the "voice in the room that starts challenging assumptions and perspectives," the officer stated "that really stayed with me because a lot of the work I do involves looking at different information and assessing intelligence and there is a lot of bias built into that..." She recognized the difficult position of the GENAD and used genderbased perspectives to critically engage with assumptions made by her colleagues. In doing so, this soldier both helped to support gender expertise during her deployment and internalized that knowledge to eliminate gender-blind viewpoints in her workplace. These viewpoints were echoed by an officer in a medical trade who argued in relation to a previous deployment, "[the citizens of X country] have rules... about talking to other genders and you still want to help them but maybe you need to put those genders [on teams] to help the people so they can actually have a conversa- 
tion and seek help." Again, this officer emphasized the importance of collaboration with local communities, which highlights both the diverse roles performed by modern military personnel and that she recognized the importance of a gender lens in protecting populations in positions of vulnerability. These examples serve to underscore the findings of Duncanson, Woodward, and Bastick's research: militaries are deployed for far more than high-intensity warfare, and CAF members often serve various humanitarian roles during operations. These interviews demonstrate that in these instances, Canadian military personnel have recognized the importance of gender and cultural sensitivity in more effectively meeting the needs of vulnerable peoples.

The snapshot I offer suggests that CAF servicemembers may currently be more receptive to reconsidering the relationship between gender and conflict and the hierarchical gender relations between and amongst groups of servicemembers than they have been in previous decades. Comments made by military personnel indicate that the CAF may be at a critical juncture in which conditions are well-suited to interjections by feminist advocates looking to pursue lasting change in favour of gender equality. This is what Connell (1987) refers to as the "transitional" stage of hegemonic masculinity, when a "version of masculinity is established which is open to equality with women," it becomes "hegemonic among men," and hierarchy among genders is subsequently eradicated (Connell and Messerschmidt 2005, 853 cited in Duncanson 2015, 243). The incorporation of feminized traits could then create a version of masculinity that is premised on equality of genders rather than subordination of the feminine. If this new masculinity became hegemonic, then the inegalitarian qualities of what it means to embody masculine norms in the military could begin to dissolve. My findings reveal a decoupling of gender norms from the ideal performance of soldiering; servicemembers identified feminized traits as not just acceptable, but laudable. Moreover, these servicemembers demonstrated that they are open to more respectful, informed, and egalitarian gender relations within the CAF, and that they are committed to assisting people in positions of vulnerability during deployment.

\section{Is the Masculine Warrior Ideal Weakening or Evolving?}

The qualitative and quantitative findings of my interviews suggest that the CAF may be entering a transitional stage in the erosion of toxic masculinity. These soldiers' responses imply that amongst their communities, individual identification with violent masculinity is on the wane, and that militarism within the institution is being replaced, or at least augmented, with concern for a more robust understanding of human security. A highly optimistic reading of these results would indicate that we can foresee a regendered military, one less concerned with the traditional machismo of warfare and more focused on egalitarian relationships within the institution and dedicated to peace and stability on operations. Yet, Duncanson (2015) and Duncanson and Woodward (2016) argue that this apparent shift could also be indicative of a more insidious trend: re-establishing hegemonic masculinity in accordance with a colonial narrative of "civilizing" amidst the "chaos of tribal warfare" (Razack 2000, 128). In other words, male dominance is not eroding, but it has become increasingly untenable to maintain that dominance through brute force. In response, military institutions have begun to cloak racist and imperialist aims behind the guise of humanitarianism and gender equality without fundamentally changing the structures that permit exploitation of women and racialized processes of othering. To return to the example of the Somalia Affair, Sherene Razack (2000) demonstrates that the national mythology of Canadian peacekeepers has been employed to conceal horrific human rights abuses perpetrated by Canadian soldiers against Somali citizens. Although the Canadian Airborne Regiment was disbanded, it serves here to point to the dangers of trusting in the "powerful and seductive story of the west bringing human rights and democracy to non-Western countries" (Razack 2004, 47 cited in Duncanson and Woodward 2016, 237). Additional research will be necessary to determine if traditional militarized masculinity is being replaced by new hierarchical relationships along intersections of race and culture, and if feminine attributes are being co-opted to accomplish military objectives that are at odds with the WPS agenda. 
As Duncanson (2015) emphasizes, the hegemony of masculinity can only be extricated from the military if men are encouraged to "not so much change their ways as to change the way in which they negotiate their identities in relation to others" (233). This admonition underscores that undoing hegemonic masculinity is primarily about how masculinity is employed to develop and justify gender hierarchy; masculine gender performance is only problematic in so far as it rationalizes oppression and violence. In other words, if Canadian soldiers are using the archetype of the "white knight" to justify neo-colonialist militarism, then this is clear evidence that militarized masculinity has simply adopted a new vocabulary, rather than being indicative of a transformative shift in the gender culture of the organization (see Razack 2004).

Unfortunately, the interview questions selected for this study could not be used to examine if militarized masculinity in the CAF has adopted a vocabulary of neocolonialist militarism. Although my interview questions did ask if "gender guidance was something that some countries would benefit from more than others?", responses could not clearly be used to suggest this kind of othering was at play. Many interviewees responded affirmatively to suggest that Canada was more advanced in its attitudes towards women but failed to indicate what nation or culture they believed Canada surpassed. Several participants suggested Canada was "more advanced than the Americans" or "the British," which does not indicate the establishment of a new racialized hierarchy. Nevertheless, some interviewees suggested that several countries, particularly in Africa and the Middle East, were not "advanced" enough to implement GBA+. An interviewee suggested, "how about worrying about getting food and water and then we'll worry about some other things.... For other nations, if all of your basic needs aren't satisfied then why don't you work on those first?" Perhaps more problematically, another participant argued that, "anyone in the western world will have the same sensibilities.... You have these despot dictators and how these people are raised, they don't have the same sensibilities as us...unless you're a first world nation that's actually been able to develop a cul- ture where you respect people...." This, in combination with other disparaging comments about these regions, suggests that there are still misunderstandings about how GBA+ is to be applied and how gender impacts security and access to vital resources. These misunderstandings demonstrate not just ignorance about the relationship between gender equality and national security, but such sentiments could also spill over into the growing neocolonial logic within peacekeeping by perpetuating a racist binary of civilized/uncivilized peoples (Razack 2000). This is a crucial line of questioning as we move forward in examining shifting gender dynamics in the CAF, and feminists need to remain attuned to the ways in which this new form of apparently more "civilized" masculinity is being used to justify attitudes about racial and national superiority (see Whitworth 2004).

Scholars concerned with regendering the armed forces must also deal with the "means-ends" rationality that underpins debates about women's involvement in the military: is the application of violence ethically tenable if it serves peaceful ends? (Elshtain 1995; Pratt 2013; Sjoberg 2006). For example, the "liberation of Muslim women" was problematically used to justify the USled invasion and occupation of both Afghanistan in 2001 and Iraq in 2003 (see Abu-Lughod 2013; Riley 2013). What is the point in women's enlistment if their deployment (both domestically and internationally) produces inegalitarian outcomes that ultimately undermine security for women (Al-Ali and Pratt 2010)? Likewise, if the CAF participates in discourses that frame women as a "force multiplier" (see Summers 2013) they run the risk of encouraging local peoples to conflate the original peaceable objectives of the WPS agenda with gathering human intelligence and improving targeting, and therefore violent militaristic outcomes. Within the Canadian defence community, there is concern that this could breed distrust of military personnel within operations, and therefore it risks undermining the legitimacy of the WPS agenda and its ability to produce goodwill and stable peaceable outcomes. Those involved in drafting policy must be extremely cautious in selecting the language used to invoke the importance of servicewomen in operations to ensure they do not confuse the discourse of 
the WPS agenda with the goals and priorities of combat operations. Emphasizing the importance of recruiting and retaining women in the combat arms to improve operational efficacy must be distinguished from enhancing the representation of women in peacebuilding efforts. This will be challenging as the two approaches are profoundly intermingled in UN and NATO foundational texts on WPS, but it is essential to unpack the complementary and oppositional goals contained within gendered security sector reform as Canada moves forward. Due to the violent nature of work required in combat operations, the CAF and the Department of National Defence carry the unique burden of reconciling the military's traditional mandate with the Canadian government's current feminist approach to foreign policy. This challenge can be more easily traversed by improving engagement with the academic community and carefully reflecting on the design of GBA+ course material.

Finally, is Canada's current emphasis on "leveraging" Canadian diversity to enhance the operational capacity of the CAF (see Canada 2017, 105) encouraging military personnel to tokenize female soldiers (Duncanson $2015,9)$ ? The problem with language that encourages soldiers to view servicewomen instrumentally is that it reinforces the argument that the representation of women and women's perspectives ought to be increased because these increases will enhance the CAF's ability to achieve and sustain peace. Gender should not be seen as synonymous with "women" nor should masculinized, or feminized attributes be tethered to bodies assigned "male" or "female" at birth. In treating servicewomen as a tool to achieve peace, we fail to recognize the complex relationship of gender and vulnerability in warfare. For example, Canada's experience in Afghanistan demonstrated that young boys were particularly vulnerable to sexual predation and abuse by members of the Afghan Security Forces - this is a gendered, and indeed feminized, process that impacted only those children and teens coded male at birth (see, Parry 2016; Pugliese 2009). Likewise, servicewomen may not want to be lauded for their roles as peacekeepers and consensus builders, and any policies or approaches that limit a woman's agency in defining her professional identity are inherently at odds with feminist priorities.
For this reason, future initiatives premised on gender analysis must emphasize that gender does not equal women, and women, for that matter, is not synonymous with peace. The goal of this work must be to problematize and transform gender stereotypes to create more egalitarian relationships amongst soldiers, not to reconstruct institutionally valuable typecasting to achieve internal and operational objectives. Extra care must be taken to ensure that military postings reflect the ambitions and capability of the soldier in question, and training material on GBA+ emphasizes gender fluidity, rather than suggesting it is a fixed biological reality.

\section{Conclusion: Can Incremental Change Yield Transformative Results?}

The question of change, and of measuring change, is indeed a difficult one. In this article, I focused on CAF servicemembers' self-perception, both individually and relationally, as one possible avenue through which we might apprehend feminist progress. I am not suggesting that my research findings can be used to demonstrate that the problems within CAF gender culture have been resolved. Instead, I am suggesting that within the CAF, there exist opportunities to pursue feminist change in order to attain a more egalitarian military and a more peaceable international community. Comments made by military personnel interviewed in this article indicate that personnel within the CAF are open to enhancing their education on gender-based issues both institutionally (within the CAF) and in operations (during deployment), and to finding ways to relate more equitably with their colleagues. Despite the recurring cases of gender-based discrimination and sexual misconduct, feminists ought not to give up on the military. As Duncanson, Woodward, and Bastick highlight, what is needed now is greater engagement. Moreover, there are numerous institutional openings through which engagement is now possible; genderbased analysis and the WPS agenda are featured prominently in Canada's current defence policy (Canada 2017), and the Department of National Defence has a strong mandate from the current government to prioritize inclusivity in all of its decisions. 
The goal of this article has been to optimistically probe my interview data with a feminist lens; to pull at areas of weakness in the combat masculine warrior paradigm and to identify points where we can continue to push for change. This further substantiates Duncanson and Woodward's (2016) argument, that through incremental change and continued engagement, we may ultimately witness a larger transformation in military gender culture. The success of initiatives in pursuit of change in the gender culture of the CAF will not just depend on members' attitudes, but also on the policies enacted to enable change, and the language invoked in service of these initiatives. CAF policy must reflect the full diversity of experiences and perspectives of its members to ensure it is not limited by the views and assumptions of the military's majority culture.

\section{Endnotes}

1. Servicemembers refers to the soldiers, sailors, and aviators of all genders who comprise the Canadian Armed Forces.

2. Rules and regulations in this question referred to items including but not limited to mandatory Genderbased Analysis Plus (GBA+) training to ensure the application of a gendered lens to policy making and implementation, the instatement of Gender Advisors in the Canadian military, bystander training designed to discourage servicemembers from turning a blind eye to sexual misconduct, and mandatory NATO Women, Peace and Security courses prior to deployment. 


\section{References}

Abu-Lughod, Lila. 2013. Do Muslim Women Need Saving? Boston: Harvard University Press.

Al-Ali, Nadje, and Nicola Pratt. 2010. What Kind of Liberation? Women and the Occupation of Iraq. Berkeley: University of California Press.

Bastick, Megan, and Claire Duncanson. 2018. "Agents of Change? Gender Advisors in NATO Militaries." International Peacekeeping 25 (4): 554-77.

Berthiaume, Lee. 2020. "Military Must Nearly Double Annual Female Recruitment to Reach Target: Study." CTV News, January 22. https://www.ctvnews.ca/canada/military-must-nearlydouble-annual-female-recruitment-to-reach-targetstudy-1.4778063.

Bulmer, Sarah, and Maya Eichler. 2017. "Unmaking Militarized Masculinity: Veterans and the Project of Military-to-Civilian Transition." Critical Military Studies 3 (2): 161-81.

Butler, Judith. 2011. Gender Trouble: Feminism and the Subversion of Identity. New York: Routledge.

Canada. 2019. "Women in the Canadian Armed Forces: Backgrounder." Ottawa: National Defence and the Canadian Armed Forces. March 7. http:// www.forces.gc.ca/en/news/article.page? doc=women-inthe-canadian-armed-forces/izkjqzeu.

Canada. 1998. "Chief Land Staff Gender Integration Study: The Experience of Women Who Have Served in the Combat Arms." Karen Davis. Sponsor Research Report 98-1. Ottawa: Personnel Research Team. Print.

Canaday, Margot. 2003. "Building a Straight State: Sexuality and Social Citizenship Under the 1944 GI Bill." The Journal of American History 90 (3): 935-57.

Carreiras, Helena. 2006. Gender and the Military: Women in the Armed Forces of Western Democracies. New York: Routledge.
Chappell, Louise, and Georgina Waylen. 2013. "Gender and the Hidden Life of Institutions." Public Administration 12 (2): 599-615.

Cockburn, Cynthia. 2010. "Gender Relations as Causal in Militarization and War: A Feminist Standpoint." International Feminist Journal of Politics 12 (2): 139-57.

Cockburn, Cynthia. 2011. "Snagged on the Contradiction: NATO, UNSCR 1325, and Feminist Responses." Annual Meeting of No to War-No to NATO, Dublin, April 15-17, 2011.

Connell, Raewyn W. 1987. Gender and Power: Society, the Person and Sexual Politics. Cambridge: John Wiley $\&$ Sons.

Connell, Raewyn W. 1995. Masculinities. Berkeley: University of California Press.

Connell, R. W. 2002a. Gender. Cambridge: Polity Press.

Connell, R. W. 2002b. "Masculinities, the Reduction of Violence, and the Pursuit of Peace." In The Post War Moment: Militaries, Masculinities and International Peacekeeping, edited by Cynthia Cockburn and Dubravka Zarkov, 33-40. London: Lawrence and Wishart.

Connell, R. W. 2005. "Change Amongst the Gatekeepers: Men, Masculinities, and Gender Equality in the Global Arena." Signs: Journal of Women in Culture and Society 30: 1802-25.

Connell, Raewyn, and James W. Messerschmidt. 2005. "Hegemonic Masculinity: Rethinking the Concept." Gender \& Society 19 (6): 829-59.

Connolly, Amanda. 2020. "Canadian Forces Targeting 'Military Culture' in New Plan to Root Out Sexual Misconduct." Global News, October 28. https://globalnews.ca/news/7427136/canadian-forcessexual-misconduct/. 
Davies, Sara E., and Jacqui True, eds. 2018. The Oxford Handbook of Women, Peace and Security. Oxford: Oxford University Press.

Davis, Karen Dianne, ed. 2007. Women and Leadership in the Canadian Forces: Perspectives and Experience.

Ottawa: Canadian Defence Academy Press.

Deschamps, M. 2015. External Review into Sexual Misconduct and Sexual Harassment in the Canadian Armed Forces. Ottawa: External Review Authority.

Duncanson, Claire. 2009. "Forces for Good? Narratives of Military Masculinity in Peacekeeping Operations." International Feminist Journal of Politics 11 (1): 63-80.

Duncanson, Claire, and Rachel Woodward. 2016. "Regendering the Military: Theorizing Women's Military Participation." Security Dialogue 47 (1): 3-21.

Duncanson, Claire. 2015. "Hegemonic Masculinity and the Possibility of Change in Gender Relations." Men and Masculinities 18 (2): 231-48.

Dunivin, Karen O. 1994. "Military Culture: Change and Continuity." Armed Forces \& Society 20 (4): 53233.

Eichler, Maya. 2014. "Militarized Masculinities in International Relations." The Brown Journal of World Affairs 21 (1): 81-93.

El-Bushra, Judy. 2007. "Feminism, Gender, and Women's Peace Activism." Development and Change 38 (1): 131-47.

Elshtain, Jean Bethke. 1995. Women and War. Chicago: University of Chicago Press.

Enloe, Cynthia. 2014. Bananas, Beaches and Bases: Making Feminist Sense of International Politics. Berkeley: University of California Press.

Enloe, Cynthia. 2000. Maneuvers: The International Politics of Militarizing Women's Lives. Berkeley:
University of California Press.

Etchart, Linda. 2015. "Demilitarizing the Global: Women's Peace Movements and Transnational Networks." In The Oxford Handbook of Transnational Feminist Movements, edited by Rawwida BakshSoodeen and Wendy Harcourt, 702-22. Oxford: Oxford University Press.

Febbraro, Angela. 2007. "Gender and Leadership in the Canadian Forces Combat Arms: Perspectives of Women Leaders." In Women and Leadership in the Canadian Forces: Perspectives and Experiences, edited by Karen D. Davis, 93-139. Kingston, ON: Canadian Defence Academy Press.

Frazer, Elizabeth, and Kimberly Hutchings. 2014. "Revisiting Ruddick: Feminism, Pacifism and Nonviolence." Journal of International Political Theory 10 (1): 109-24.

Gill, Ritu, and Angela R. Febbraro. 2013. "Experiences and Perceptions of Sexual Harassment in the Canadian Forces Combat Arms." Violence Against Women 19 (2): 269-87.

Higate, Paul. 2007. "Peacekeepers, Masculinities, and Sexual Exploitation.” Men and Masculinities 10 (1): 99119.

Hinojosa, R. 2010. "Doing Hegemony: Military, Men, and Constructing a Hegemonic Masculinity." The Journal of Men's Studies 18 (2): 179-94.

Hurley, Matthew. 2018. “The 'Genderman':

(Re)negotiating Militarized Masculinities when 'Doing Gender' at NATO.” Critical Military Studies 4 (1): $72-$ 91.

Kronsell, Annica, and Erika Svedberg, eds. 2011. Making Gender, Making War: Violence, Military and Peacekeeping Practices. New York: Routledge.

Lane, Andrea. 2017. "Special Men: The Gendered Militarization of the Canadian Armed Forces." International Journal 72 (4): 463-83. 
Lorentzen, Lois Ann, and Jennifer E. Turpin, eds. 1998. The Women and War Reader. New York: NYU Press.

Mann, Michael. 2018. "Have Wars and Violence Declined?" Theory and Society 47 (1): 37-60.

Mercier, Noémi, and Alec Castonguay. 2014. "Our Military’s Disgrace." Maclean's, May 16.

Minister of National Defence. 2017. Strong, Secure, Engaged: Canada's Defence Policy. Ottawa: Department of National Defence.

Nagel, Joanne. 1998. "Masculinity and Nationalism: Gender and Sexuality in the Making of

Nations." Ethnic and Racial Studies 21 (2): 242-69.

NATO. 2018. Annual Diversity and Inclusion Report 2018. NATO Human Resources.

https:/www.nato.int/nato_static_fl2014/assets/pdf/ 2020/7/pdf/2018-annual-

diversity_inclusion_report.pdf.

O’Hara, Jane. 1998. "Rape in the Military.” Maclean's, May 25. http://www.macleans.ca/news/canada/rape-inthe-military/.

Peach, Lucinda Joy. 1997. "Behind the Frontlines: Feminist Battles over Women in Conflict." In Wives and Warriors: Women and the Military in the United States and Canada, edited by Laurie Lee Weinstein and Christie C. White, 199-235. Westport, CT:

Greenwood Publishing Group.

Parry, Tom. 2016. "Canadian Soldiers Not Ordered to Ignore Sex Abuse of Afghan Children: Inquiry." CBC, April 12. https://www.cbc.ca/news/politics/canadianforces-afghan-abuse-1.3532315.

Women's International League for Peace and Freedom. 2020. "National-Level Implementation." Peacewomen: Women's International League for Peace and Freedom. Webpage. https://www.peacewomen.org/memberstates.
Peterson, V. Spike. 2007. "Thinking Through Intersectionality and War." Race, Gender \& Class 14 (3/4): 10-27.

Pratt, Nicola. 2013. "Weaponizing Feminism for the 'War on Terror,' Versus Employing Strategic Silence." Critical Studies on Terrorism 6 (2): 327-31.

Pugliese, David. 2009. "Former Soldier Still Fights to Protect Afghan Boys from Abuse." The Ottawa Citizen, September 9. http://www.ottawacitizen.com/news/ Former+soldier+still+fights+protect + Afghan+boys+fro m+abuse/2014418/story.html.

Razack, Sherene. 2000. "From the 'Clean Snows of Petawawa': The Violence of Canadian Peacekeepers in Somalia." Cultural Anthropology 15 (1): 127-63.

Razack, Sherene. 2004. Dark Threats and White Knights: The Somalia Affair, Peacekeeping, and the New Imperialism. Toronto: University of Toronto Press.

Report of the Secretary General on Women, Peace and Security. 2019. UNSC, UN Doc S/2019/800.

Riley, Robin L. 2013. Depicting the Veil: Transnational Sexism and the War on Terror. London: Zed Books Ltd.

Schippers, Mimi. 2007. "Recovering the Feminine Other: Masculinity, Femininity, and Gender Hegemony." Theory and Society 36 (1): 85-102.

Shepherd, Laura J. 2011. "Sex, Security and Superhero(in)es: From 1325 to 1820 and Beyond." International Feminist Journal of Politics 13 (4): 504-21.

Sjoberg, Laura. 2013. Gendering Global Conflict: Toward a Feminist Theory of War. New York: Columbia University Press.

Sjoberg, Laura, and Sandra Via. 2010. Gender, War, and Militarism: Feminist Perspectives. Santa Barbara, CA: ABC-CLIO. 
Sjoberg, Laura, ed. 2009. Gender and International

Security: Feminist Perspectives. New York: Routledge.

Sjoberg, Laura. 2006. Gender, Justice, and the Wars in Iraq: A Feminist Reformulation of Just War Theory.

Washington, DC: Lexington Books.

Statistics Canada. 2016. "Sexual Misconduct in the Canadian Armed Forces." Statistics Canada Catalogue 85-603-X. Ottawa.

Statistics Canada. 2018. "Sexual Misconduct in the Canadian Armed Forces." Statistics Canada Catalogue 85-603-X. Ottawa.

Summers, Clark H. 2013. "Women: The Combat Multiplier of Asymmetric Warfare.” Military Review 93 (4): 71-78.

Szayna, Thomas S., et al. 2017. What Are the Trends in Armed Conflicts, and What Do They Mean for US Defense Policy? Santa Monica, CA: Rand Arroyo Center.

Taber, Nancy. 2018. "After Deschamps: Men, Masculinities, and the Canadian Armed Forces." Journal of Military, Veteran and Family Health 4 (1): 100-07.

Taber, Nancy. 2017. "The Canadian Armed Forces: Battling Between Operation HONOUR and Operation Hop on Her." Critical Military Studies 6 (1): 19-40.

Tait, Victoria. 2015. "Gender and the 21st Century Threat Environment." SITREP: The Journal of the Royal Canadian Military Institute 75 (1): 5-9.

United Nations. 2005. "Responsibility to Protect." United Nations Office on Genocide Prevention and the Responsibility to Protect. https://www.un.org/en/ genocideprevention/about-responsibility-toprotect.shtml.
United States Institute of Peace. 2020. "What is UNSCR 1325: An Explanation of the Landmark Resolution on Women, Peace and Security." United States Institute of Peace. Webpage. https:// www.usip.org/gender_peacebuilding/ about_UNSCR_1325.

Whitworth, Sandra. 2004. Men, Militarism, and UN Peacekeeping: A Gendered Analysis. Boulder, CO: Lynne Rienner Publishers.

Whitworth, Sandra. 2005. "Militarized Masculinities and the Politics of Peacekeeping: The Canadian Case." In Critical Security Studies and World Politics, edited by Ken Booth, 89-106. Boulder, CO: Lynne Rienner Publishers.

Winslow, Donna. 1999. "Rites of Passage and Group Bonding in the Canadian Airborne." Armed Forces \& Society 25 (3): 429-57.

Winslow, Donna. 2000. "Misplaced Loyalties: The Role of Military Culture in the Breakdown of Discipline in Two Peace Operations." Journal of Military and Strategic Studies 6 (3): 293-309.

Winslow, Donna, and Jason Dunn. 2002. "Women in the Canadian Forces: Between Legal and Social Integration." Current Sociology 50 (5): 641-67. 